\title{
Akademiske Grundtvig-tolkninger.
}

Fra modernisme til nymarxistisk kritik. Litteraturkritiske holdninger. En studiebog redigeret af Oluf Bohn. Schultz Tema-bøger. Kbh. 1970.

Indtrykket af denne lille bog er forståeligt nok meget blandet. Under redaktion af en gymnasielærer har 4 amanuenser ved Aarhus Universitet påtaget sig at tolke de samme to digte for derved at belyse den metode, de anvender, og den kritiske holdning, de indtager over for ældre og nyere digtning. Bogens værdi forøges ved en ordliste og optryk af de nødvendige tekster, men forringes desværre af mange forstyrrende trykfejl. Da det ene af de to behandlede digte er af Grundtvig - det andet er af Rifbjerg - viser bogen imidlertid tillige, hvordan moderne akademikere i dag behandler Grundtvigs poesi. Niels Egebaks Grundtvig-tolkning var i fjor tillige trykt i Grundtvig-Studier. De tre andre tolkninger er af Jørgen Bang, Flemming Harrits og Finn Stein Larsen.

Udgangspunktet er for alle bidragyderne moderne digtning og kritik; men to af de fire indtager på hver sin måde en marxistisk holdning, og bogen klinger ud i et hidsigt opgør mellem dem. De to andres holdning forbliver politisk og ideologisk neutral. For at give bogen en teoretisk indledning har man medtaget to essays af københavneren Torben Brostrøm og nordmanden Knut Johansen; den sidstnævnte er marxist, den førstnævnte introducerede modernismen i dansk kritik 1959. Det er ikke helt tilfældigt, at en af deltagerne i den afsluttende debat taler om sin »blandede landhandel« - det karakteriserer bogen.

Hovedsagen er dog de fire tolkninger af De Levendes Land, og det afgørende spørgsmål, bogen stiller en Grundtvig-forsker, dette: er det livssyn, der udtrykkes i dette digt, virkelig en idealistisk ideologi?

Hvor uenige de fire tolkere end iøvrigt er, synes de alle at besvare dette spørgsmål med ja. Ligesom de er enige om, at en sådan ideologi uhjælpeligt tilhører fortiden. Det er derfor højst besynderligt at læse den norske marxists indledningsessay. Det tager nemlig sit udgangspunkt i en udpræget idealistisk kritikers tanker fra forrige århundrede, der blot videreføres og omtydes marxistisk med henvisning til Herbert Marcuse. På tilsvarende måde hævder Niels Egebak i den afsluttende debat: »Grundtvig kan kun bekæmpe den romantiske ideologi med en ny ideologi, som må gå ind på den bekæmpede ideologis præmisser, bruge dens begreber og sætte dem ind i en ny sammenhæng. Det er det, han gør med De Levendes Land.« (S. I40.) Hvis Egebak havde ret heri, var det umuligt nogensinde at frigøre sig fra den romantiske ideologis dialektik.

Men det er netop det, Grundtvig gør: »Mit Land, siger Livet, er Himmel og Jord! Hvor Kiærlighed boer.« Livet er ikke begrænset til et luftigt evighedsrige, der fortsætter efter døden; det findes også her og nu, men kun hvor der er kærlighed. Det er m. a. o. kærligheden, der skaber liv - ikke drøm og længsel, endsige ideologi. Og kærligheden er ikke blot immateriel, men også materiel, fysisk. Den er på én gang jordisk og himmelsk - altså ikke blot menneskelig, men også guddommelig, skabende. Grundtvigs kristne realisme sprænger alle ideologier, såvel idealistiske som materialistiske. Den menneske- 
lige eros har en gnist i sig af den guddommelige agape - så omfattende er Grundtvigs både-og.

Stein Larsens tolkning, »Barnet og fortrylleren« er nok den, der stemmer bedst med digtet selv - og dog den originaleste. Men den principielle forskel mellem indledningsstroferne og slutningsafsnittet synes her at fortone sig. Selv lod Grundtvig digtet ligge til 1832, da det blev trykt i en børnesalmebog (»O deilige Land«). Den oprindelige skikkelse blev først trykt af Sv. Grundtvig 1883 .

Den dialektik mellem legemligt og sjæleligt, Grundtvigs samtid hævdede, benægtede Grundtvig: »Mein Gegensatz ist Leben und Tod,« er et af hans udtryk derfor. Grundtvig siger nemlig ikke: »Jeg tænker, altså er jeg,« men: »Jeg føler, altså er jeg.« Og den grundfølelse, der forvisser ham om hans eksistens, er på én gang legemlig og sjælelig. Grundmodsætningen var liv og død, og det skel, han dermed drager, går på tværs af skellet mellem legemligt og sjæleligt. Livet holder sammen på legeme og sjæl, døden skiller dem ad.

Det livssyn, Grundtvig hævder i De Levendes Land, er altså forskelligt fra det platoniske. Opstandelsen fra de døde er ikke sjælens tilbagevenden til en transcendent evighedsverden, som filosofien eller digtningen kan beskrive, men menneskets regnskabsaflæggelse og eftergivelse af dets gæld i kraft en overmenneskelig livsmagt: kærligheden, der skaber nyt liv på jorden, men udgår fra et overjordisk liv. Utopien er m. a. o. her og nu - men kun »hvor Kiærlighed boer«.

At dette livssyn måtte få konsekvenser for Grundtvigs holdning over for det jordiske samfundsliv, er klart og ses af hans politiske indsats. Der er dog meget i hans kulturprogram, som står tilbage at gennemføre.

William Michelsen

Om Grundtvig som livskunstner.

Aage Henriksen: Gotisk tid. Fire littercre afhandlinger. Gyldendal. København

I97I.

Når professor Aage Henriksen her genoptrykker sin lærde studie over Grundtvigs mellemværende med Jens Baggesen $1815^{-1} 7$ fra tidsskriftet Kritik ( 1 . årgang nr. I-2), er det måske bl. a. for at prøve, om det nu skulde lykkes denne Baggesen-kender og -elsker at afvinde sin tids Grundtvigkendere og -elskere et lignende svar, som Baggesen fik af Grundtvig i den rimbrevsstrid, Baggesen meget indforstået kaldte »Valhalla-Legen«. Om det vil lykkes, afhænger i nogen grad af, om de to parter vil forstå hinandens sprog lige så godt, som de to digtere forstod hinanden.

Baggesens i flere henseender væsentlige betydning for Grundtvig er hidtil stærkest fremhævet af Gustav Albeck, der i sin afhandling Omkring Grundtvigs Digtsamlinger tillige har identificeret Grundtvig med signaturen $G$ under en sympatisk-kritisk gennemgang af Baggesens forfatterskab i Lærde Efterretninger I808-09, da Baggesens aktier ikke stod højt. Men Grundtvig gav 